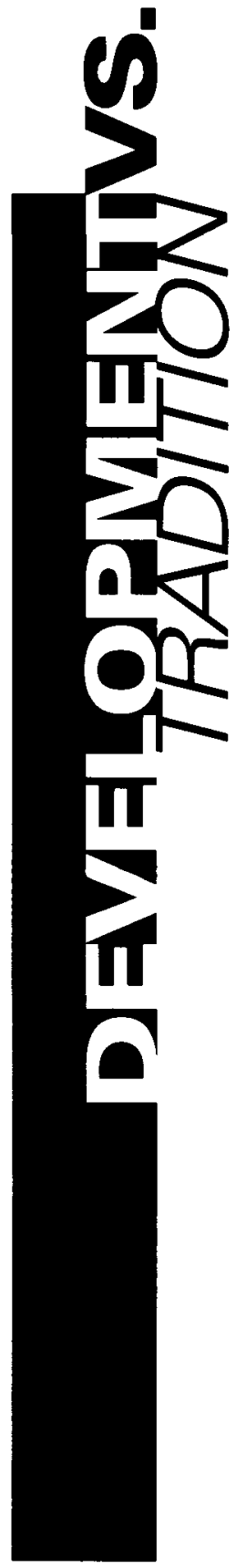

\title{
THIRD INTERNATIONAL CONFERENCE
}

OF THE INTERNATIONAL ASSOCIATION FOR THE STUDY OF TRADITIONAL ENVIRONMENTS

OCTOBER 8-11, 1992

PARIS, FRANCE

The third conference of the International Association for the Study of Traditional Environments (IASTE) addressing the theme "Development vs. Tradition: The Cultural Ecology of Dwellings and Settlements" will be held October 8-11, 1992, at the Union International des Chemins de Fer in Paris, France.

The conference will focus on the dialectic tension and the potential balance between development and tradition, given the ongoing effects of modernization. The final schedule includes 125 papers from scholars representing 40 countries. Keynote speakers include Oleg Grabar, Anthony King, Paul Oliver, Zmarak Shalizi, Wolf Tochtermann, and Gerard Toffin.

For registration information, please contact:

\author{
IASTE '92 Conference \\ Center for Environmental Design Research \\ 390 Wurster Hall \\ University of California \\ Berkeley, CA 94720, USA \\ Telephone (510) 547-7814 \\ Fax (510) 643-5571
}




\section{Annales}

\section{Économies Sociétés Civilisations}

Fondateurs : Lucien FEBVRE et Marc BLOCH. Directeur : Fernand BRAUDEL Revue bimestrielle publiée depuis 1929 avec le concours de l'École des Hautes Etudes en Sciences Sociales

\section{SYSTÈMES D'EXPLOITATION}

Charles VAN ONSELEN, Paternalisme et violence dans les fermes du Transvaal de 1900 à 1950

Alessandro STELLA, L'esclavage en Andalousie à l'époque moderne

\section{L'ART et SES PRATIQUES}

Peter J. A. N. RIETBERGEN, Art, pouvoir et politique dans l'ordre augustinien au XVII'e siècle

Alain GUERREAU, Édifices médiévaux, métrologie, organisation de l'espace, à propos de la cathédrale de Beauvais

Croyances, religions et sociétés (comptes rendus)

\section{SOCIÉTÉS PLURICULTURELLES}

Michel DUBUISSON, Le grec à Rome à l'époque de Cicéron, extension et qualité du bilinguisme

Claire et Jean-Marie PAILLER, Une Amérique vraiment latine : pour une lecture " dumézilienne " de I'Inca Garcilaso de la Vega

\section{MÉTIER D'HISTORIEN, 4}

Paule BRAUDEL, Les origines intellectuelles de Fernand Braudel : un témoignage

Youri BESSMERTNY, Les Annales vues de Moscou

Bernard LEPETIT et Jacques REVEL, L'expérimentation contre l'arbitraire

RÉDACTION : 54, Boulevard Raspail, 75006 PARIS

$\begin{aligned} \text { ABONNEMENTS } 1992 & \text { - France } \\ & \text { - Étranger }: 328 \mathrm{~F} \text { - Etudiants France : } 245 \mathrm{~F} \\ & \text { - Le numéro }: 90 \mathrm{~F}\end{aligned}$

Les abonnements doivent être souscrits auprès d'Armand COLIN Éditeur,

B.P. 22 - 41353 VINEUIL 
The Social Survey in Historical Perspective, 1880-1940

Martin Bulmer, Kevin Bales and Kathryn Kish Sklar, Editors

This book traces the history of the social survey in Britain and the United States (with two chapters on Germany and France), discussing the aims and interests of those who carried out the early surveys, and the links between the social survey and the growth of empirical social science. Contributors: Martin Bulmer, Kevin Bales, Kathryn Kish Sklar, Eileen Janes Yeo, Jane Lewis, E. P. Hennock, Alain Desrosieres, Steven R. Coben, Stephen P. Turner, Irmela Gorges, Jennifer Platt, Roger Davidson, Seth Koven 36334-9 Hardcover $\$ 64.50$

\section{The Making of a Saint}

The Life, Times and Sanctification of Neophytos the Recluse

\section{Catia Galatariotou}

Each case of sanctification poses the same general question: How does an individual become a Saint? This pioneering study focuses on one case of sanctification in late twelfth and early thirteenth-century Byzantium, tracing the evolution of Neophytos's idiosyncratic pursuit of selfsanctification, and placing the Saint within the context of his society at large, in Cyprus and in the Byzantine world. 39035-4 Hardcover $\$ 64.50$

\section{The French Revolution and} British Popular Politics Mark Philp, Editor

Leading scholars explore the nature and origins of the ideological conflicts between reformers and loyalists, the impact of the war with France on the organization of the British state and its relations with its people, and the extent of the threat of revolution on both British and colonial territory. 39123-7 Hardcover $\$ 49.95$
The German Experience of Professionalization

Modern Learned Professions and their

Organizations from the Early

Nineteenth Century to the Hitler Era

Charles E. McClelland

Modern learned professions (medicine, law, teaching, engineering, and others) developed in central Europe just as vigorously as in England or America. Yet their close relationship with state power led to a different historical experience of professionalization. This work explores that experience in a comprehensive way. 39457-0 $\$ 54.50$

\section{The Worlds of} Christopher Columbus William D. Phillips, Jr. and Carla Rahn Phillips

"Mr. and Mrs. Phillips, both historians at the University of Minnesota, are characteristically meticulous....they have the essential Columbus: his basic motivation, as they realize, was social ambition.... they bring out well the slow maturation of Columbus's intellect.... They write clearly, simply and conscientiously.... theirs is an excellent book for the Columbus beginner."

-The New York Times Book Review 35097-2 Hardcover $\$ 27.95$

Available in bookstores or write:

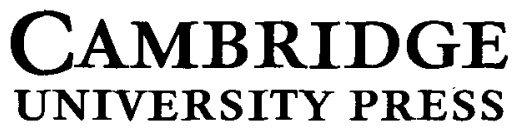

40 West 20th Street

New York, NY 10011-4211

Call toll-free 800-872-7423

MasterCard/NISA accepted.

Prices subject to change. 


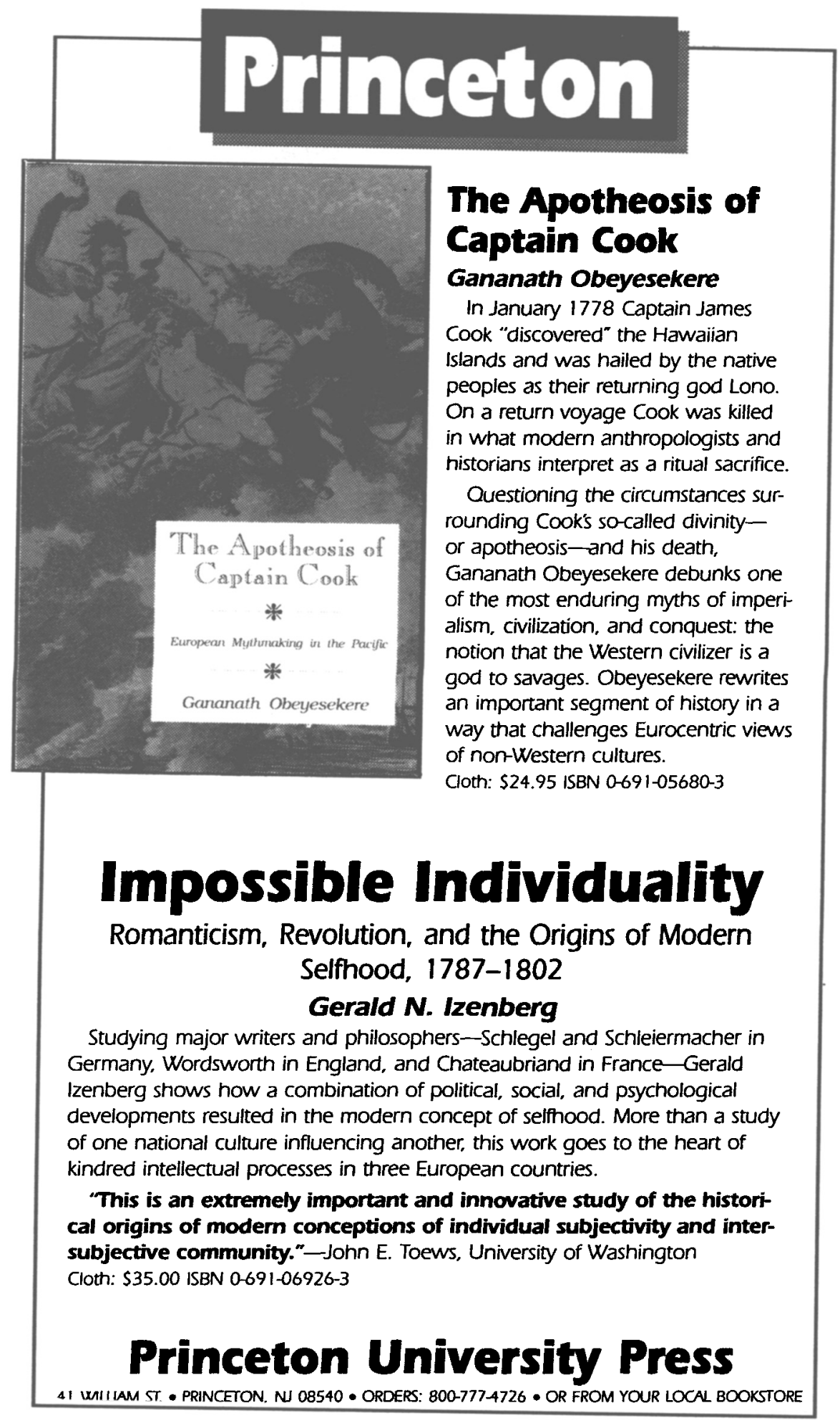


Comparative Studies in Society and History is a forum for presentation and discussion of new research into problems of change and stability that recur in human societies through time or in the contemporary world. It sets up a working alliance between specialists in all branches of the social sciences and humanities. Debate and review articles bring the general reader in touch with current findings and issues.

\section{NOTES FOR CONTRIBUTORS}

Contributions may be descriptive, analytical, or theoretical. Any article not in itself comparative may be accepted if it lends itself to comment that will place it in comparative perspective. Correspondence with the editors prior to the submission of articles will help to enable them to obtain such comment or a companion study. Emphasis in comparative studies may be either on similarities or, if these are significant enough and call for some recasting of generalizations, on differences. All contributions and editorial correspondence should be sent to the Editors, Comparative Studies in Society and History, 102 Rackham Building, University of Michigan, Ann Arbor, Michigan 48109-1070.

Two copies of each contribution, preferably accompanied by a stamped, addressed envelope, should be submitted. Both text and footnotes should be clearly typed with double spacing and wide margins; footnotes should appear on separate pages at the end of the article. Illustrations may be included by arrangement with the editors. 
Volume $34 \quad$ Number $3 \quad$ July 1992

\section{COMPARATIVE STUDIES \\ IN SOCIETY AND HISTORY}

Editorial Foreword

$405-406$

Landed Wealth and Social Status

Karin J. Machardy The Rise of Absolutism and Noble

Rebellion in Early Modern Habsburg Austria, 1570 to $1620 \quad 407-438$

William Lavely and R. BIN Wong Family Division and Mobility in North China

Constructing Local Boundaries

KERWIN L. KLEIN Frontier Tales: The Narrative Construction of Cultural Borders in Twentieth-Century California

$464-490$

Stacy Leigh PIGg Inventing Social Categories Through Place: Social Representations and Development in Nepal

ANN STOLER Sexual Affronts and Racial Frontiers: European Identities and the Cultural Politics of Exclusion in Colonial Southeast Asia

CSSH Discussion

Ernestine L. McHugh Dialogue, Structure, and Change in Himalayan Anthropology. A Review Article

JOHN M. JORDAN Retooled Liberalism? A Review Article

Michael O'Brien Conservative Thought in the Old South.

A Review Article

$566-576$

Cambridge University Press

The Edinburgh Building, Shaftesbury Road, Cambridge CB2 2RU

40 West 20th Street, New York, NY 10011

10 Stamford Road, Oakleigh, Melbourne 3166, Australia

(C) 1992 Sóciety for the Comparative Study of Society and History

Printed in the United States of America 